\title{
Waarheen stuurt het Tijdschrift het herstelrecht?
}

\author{
Lode Walgrave
}

$\mathrm{Al}$ in de jaren negentig was de KU Leuven een belangrijke broedplaats van herstelrecht. Enkele concrete experimenten werden er begeleid, allerlei lokale denk- en werkgroepen waren er actief, veelgelezen publicaties verschenen, twee actieve internationale netwerken hadden hun zetel in Leuven (het European Forum for Mediation and Restorative Justice en het International Network for Research on Restorative Justice), meerdere lokale en internationale studiedagen, congressen en seminars vonden er plaats. Op een ervan sprak John Blad mij aan over een nieuw op te richten Tijdschrift voor Herstelrecht. Toegegeven, ik had een kleine bijgedachte. 'Waarom hadden wij daar nog niet aan gedacht? Wij blijven broeden op een idee, maar het is de Hollandse ondernemingsgeest die er meteen een tijdschrift rond organiseert.'

Natuurlijk was ik graag bereid deel uit te maken van de redactie. Aanvankelijk waren we met negen: naast John Blad en ikzelf ook nog Jan van Lieshout, Johan Kunst, Marjon van der Leer, Judith Leest, Rob van Pagée, Bram Peper, Annemieke Wolthuis. John Blad was (natuurlijk) de hoofdredacteur. Redactieleden gingen en kwamen. In het eerste nummer van 2020 worden dertien redactieleden vermeld. Van de oorspronkelijke groep is alleen Annemieke Wolthuis overgebleven.

Mede dankzij Johns gedreven en geïnspireerde inzet, kreeg ik in de redactievergaderingen vaak de aangename indruk betrokken te zijn in een soort samenzwering met het oog op een betere wijze van omgaan met de gevolgen van misdrijven en andere onrechtmatigheden en conflicten. We waren het - gelukkig - niet steeds eens, wat tot levendige discussies leidde. Is het herstelrechtelijke uitgangspunt echt zo gunstig voor slachtoffers als verondersteld? Hoever reiken de mogelijkheden van het herstelrecht? Hoe verhoudt het herstelrecht zich tot het recht? Biedt het herstelrecht een alternatief voor het a priorisme van de straf? Staat straf gelijk aan intentionele leedtoevoeging? Welke relatie zien we tussen het herstelrecht in de strikte zin van het woord en de herstelgerichte praktijken in buurten, in de scholen of in de welzijnssector? De intellectuele sparringpartners respecteerden elkaar (zoals het hoort in herstelrechtelijke middens), steeds doordrongen van een oprechte bezorgdheid voor de kwaliteit, van de samenleving, van de wijze waarop conflicten en onrechtmatigheden worden aangepakt, van de teksten die in het tijdschrift zouden verschijnen.

Ik vermoed dat het nog steeds zo is. Telkens weer neem ik met veel nieuwsgierigheid kennis van een nieuw nummer. Het Tijdschrift voor Herstelrecht is meer dan een begeleider of een getuigenis van de ontwikkelingen inzake herstelrecht in Nederland en België. Het is een voorloper geworden, een richtinggever. 
En dan rijst de vraag waarheen het Tijdschrift voor Herstelrecht gaat sturen. De mainstream identificeert herstelrecht met een procesaanbod na misdrijven of bij conflicten. Na een misdrijf blijft herstelrecht aan de rand van de strafrechtelijke procedure. Dan komt het erop aan de gerechtelijke macht ervan te overtuigen zo veel mogelijk casussen door te verwijzen. De toegang tot het herstelrechtelijke aanbod blijft in gerechtelijke handen en de resultaten ervan worden beoordeeld aan de hand van traditionele gerechtelijke criteria. Het risico is dat de innoverende impuls van het herstelrecht dan geleidelijk wegebt en dat het herstelrecht verschuift naar een dadergericht alternatief, ten koste van het slachtoffer.

$\mathrm{Er}$ is een groeiend besef dat zo'n puur procesgerichte visie op herstelrecht tekortschiet. Ondanks een toenemende toepassing van herstelrechtelijke processen is het traditionele strafrecht in de laatste twee decennia niet veel veranderd (zoals ook beschreven in publicaties van Wood, Anderson \& Schiff, Lemonne, UNODC Handbook en andere). Het strafrechtsysteem blijft overbelast, de procedures blijven strak en dadergericht, vooral de lichte en jeugdmisdrijven worden verwezen, onder professionals van het strafrecht bestaat nog steeds weinig of geen begrip voor de mogelijkheden van herstelrecht, er zijn geen aanwijzingen dat meer herstelrecht heeft geleid tot minder gevangenisstraffen. Herstelrecht blijft een ornamentje in de marge van het systeem.

Niet in Nieuw-Zeeland. In 1989 plaatste het nieuwe jeugdrecht daar de family group conferencing niet in de marge, maar in het hart van de procedure. In 2004 meldde Maxwell met haar collega's dat het aantal veroordelingen en opsluitingen van minderjarigen tussen 1989 en 2001 spectaculair was gedaald. We moeten daar lessen uit trekken.

$\mathrm{Al}$ van mijn eerste stapjes in het wereldje van herstelrecht heb ik gepleit voor een meer consequente visie op herstelrecht. Dat werd een 'maximalistische visie' genoemd. Ik denk dat ik het beter een 'consequente visie' op herstelrecht zou noemen (het Tijdschrift voor Herstelrecht bood me een forum om deze visie toe te lichten en te verdedigen in de nummers 9(3) en 10(1)). Het uitgangspunt is eigenlijk simpel. Er zijn tal van instrumentele en principiële redenen om voor herstelrecht te kiezen, en die redenen verdwijnen niet als een van de betrokkenen medewerking weigert of als de feiten zeer ernstig zijn. Maar het kan wel zijn dat we dan moeten schakelen. Als vrijwillig overleg niet mogelijk of - voorlopig? - niet wenselijk is, dan moet gerechtelijke dwang worden overwogen. Maar ook de gerechtelijke dwang moet consequent de voorrang blijven geven aan sancties met een zo veel mogelijk herstellend karakter.

Voor een consequent herstelrecht is dus niet het proces, maar wel het nagestreefde hersteldoel het belangrijkste kenmerk. De uitsluitende nadruk op het proces riskeert uit te glijden naar een dadergerichte praktijk. Overlegprocessen zijn uitermate belangrijk, niet als doel, maar als middel, omdat ze de meeste kans bieden op zo veel mogelijk herstel.

Een consequent herstelrecht schikt zich dus niet in de rol van addendum bij het bestaande systeem dat bestraffing van misdrijven vooropstelt, maar het heeft de ambitie om op termijn het huidige systeem van strafrecht om te buigen tot een delictenrecht dat de voorrang geeft aan de mogelijkheden tot herstel van de 
individuele, relationele en maatschappelijke schade die door een misdrijf is veroorzaakt.

Dat is veel constructiever dan het catastrofale uitgangspunt dat misdrijven moeten worden bestraft. Het waarborgt ook dat het leed en de schade van de slachtoffers hoe dan ook een centraal aandachtspunt blijft in een herstelrechtelijk antwoord.

Het Tijdschrift voor Herstelrecht kan een beslissende rol spelen in de omslag. Het is juist dat deze omslag niet voor morgen is (en ook niet voor overmorgen). In afwachting is niets mis met de tal van herstelgerichte processen die thans worden uitgevoerd in en rond het strafrechtsysteem, maar het is niet genoeg. Het zijn oefeningen die de kwaliteit van de uitgevoerde praktijken moeten verbeteren, in afwachting van het grote werk. Als het Tijdschrift voor Herstelrecht over twintig jaar nog bestaat, zal het volwassen zijn, in de fleur van zijn leven. En dan zal hopelijk ook het herstelrecht helemaal zijn opgebloeid en het uitgangspunt zijn bij elke interventie naar aanleiding van een misdrijf. 